\title{
PRODUCTION OF 6-PENTYL- $\alpha$-PYRONE BY TRICHODERMA HARZIANUM IN SOLID-STATE FERMENTATION
}

\author{
Aline de Souza Ramos ${ }^{1,2}$, Sorele Batista Fiaux ${ }^{3}$, Selma Gomes Ferreira Leite ${ }^{2 *}$ \\ ${ }^{1}$ Farmanguinhos, Fundação Oswaldo Cruz, Rio de Janeiro, RJ, Brasil; ${ }^{2}$ Departamento de Engenharia Bioquímica, Escola de \\ Química, Universidade Federal do Rio de Janeiro, Rio de Janeiro, RJ, Brasil; ${ }^{3}$ Faculdade de Farmácia, Universidade Federal \\ Fluminense, Niterói, RJ, Brasil
}

Submitted: October 27, 2007; Returned to authors for corrections: August 26, 2008; Approved: November 02, 2008.

\begin{abstract}
Many Trichoderma species are able to produce 6-pentyl- $\alpha$-pyrone (6-PP), a lactone with coconut-like aroma. In the present work, several culture parameters were studied to enhance the production of 6-PP by Trichoderma harzianum 4040 in solid-state fermentation. Green coir powder added to a nutrient solution was used as support material for fermentation. A Plackett-Burman screening technique was applied, followed by a fractionary factorial design. The best culture conditions within the experimental domain studied were $(100 \mathrm{~g} \text { support })^{-1}$ : sucrose, $3 \mathrm{~g}$; $\mathrm{NaNO}_{3}, 0.24 \mathrm{~g}$; $\left(\mathrm{NH}_{4}\right)_{2} \mathrm{SO}_{4}, 0.18 \mathrm{~g} ; \mathrm{KH}_{2} \mathrm{PO}_{4}, 0.1 \mathrm{~g}$; inoculum concentration, $2.2 \times 10^{6}$ spores; moisture level, $55 \%$. The temperature established was $28^{\circ} \mathrm{C}$. The fermentation under the selected conditions led to a 6-PP production six times higher $(5.0 \mathrm{mg} / \mathrm{g}$ dry matter) than the initial one $(0.8 \mathrm{mg} / \mathrm{g}$ dry matter) after seven days of cultivation.
\end{abstract}

Key words: 6-pentyl- $\alpha$-pyrone, Trichoderma harzianum, solid-state fermentation, experimental design

\section{INTRODUCTION}

Flavour compounds represent over a quarter of the world market for food additives (11). Most of the flavour compounds used is produced via chemical synthesis or by extraction from natural materials. The increasing demand for natural additives in food industries and difficulties found in production and extraction of flavours from plants lead to the search of alternative routes based on microbial biosynthesis or bioconversion. Trichoderma species are reported as good producers of the $\delta$ lactone 6-pentyl- $\alpha$-pyrone (6-PP) $(3,16)$. This lactone was found to be the major volatile compound contributing to the coconutlike aroma in cultures of Trichoderma viride (5). Fungicide properties of this compound were also reported $(5,16)$.

The microbial fermentation seems to be a good route for 6PP production since its chemical synthesis is of difficult accomplishment (15). It was reported that 6-PP production is apparently related to antagonism response of some Trichoderma species to disadvantageous culture conditions (13) and solid- state fermentation can give higher yields of 6-PP than submerged fermentation $(1,15)$.

Agro-industrial residues are generally considered the best substrates for solid-state fermentation processes, mainly due to the low cost. Nowadays, world concerns about the environment enhanced the importance of the use of such materials. Among several agro-industrial residues in Brazil, green coir powder has become a major problem, due to the large amount of material and its slow decomposition process (4).

In solid-state fermentation, the solid substrate provides the base and the nutrients to the development of microorganisms. In some cases the nutrients may be absent or avaiable in suboptimal concentrations and it becomes necessary to supplement substrates with them. In any fermentation process, the nature and amount of each nutrient and culture conditions are of extremely importance to enhance production (12). It is frequently necessary to study a large number of variables to find out the best culture conditions. Statistical experimental designs represent a good way to evaluate this large number of variables.

*Corresponding Author. Mailing address: Departamento de Engenharia Bioquímica, Escola de Química, UFRJ, Cidade Universitária CT-Bloco E, Lab 113, CEP 21941-909, Rio de Janeiro, RJ, Brasil. Tel.: (55) (21) 2562-7578, fax: (55) (21) 2562-7567. E-mail: selma@eq.ufrj.br 
This approach reduces the experimental effort and allows the researches to study the effects of several factors and the interactions between them at the same time $(9,18)$.

The aim of the present study was to enhance 6-PP production by Trichoderma harzianum 4040 in solid-state fermentation using green coir powder as support material. A sequence of two fractionary factorial designs was used to achieve this purpose.

\section{MATERIALS AND METHODS}

\section{Microorganism and culture conditions}

T. harzianum 4040 obtained from the collection of "Departamento de Micologia, Fundação Oswaldo Cruz (FIOCRUZ)" was used. Spores obtained by culturing fungus in potato dextrose agar (Himedia Labs, Mumbai, India) for seven days at $28^{\circ} \mathrm{C}$ were resuspended in saline solution $(0.9 \% \mathrm{NaCl})$ and quantified in Neubauer chamber. Cultures were performed without stirring, in $250 \mathrm{~mL}$ cotton-plugged Erlenmeyer flasks with $4.5 \mathrm{~g}$ of green coir powder (smaller than $1.19 \mathrm{~mm}$ or 14 mesh Tyler) moisturized with nutrient solution and spore suspension. Initially, $4.5 \mathrm{~mL}$ of nutrient solution and $1 \mathrm{~mL}$ of spore suspension containing $1 \times 10^{7}$ spores $/ \mathrm{mL}$ were added to $4.5 \mathrm{~g}$ of green coir powder, leading to the moisture level of $55 \%$. Green coir powder (provided by Embrapa - Empresa Brasileira de Pesquisa Agropecuária - Brazil) was characterized by Rosa et al. (14). Green coir powder and nutrient solutions were individually autoclaved at $121^{\circ} \mathrm{C}$ for $20 \mathrm{~min}$ before inoculation. The initial conditions were (100g support) $)^{-1}$ : sucrose, $3 \mathrm{~g} ;\left(\mathrm{NH}_{4}\right)_{2} \mathrm{SO}_{4}, 0.094$ $\mathrm{g}$; yeast extract, $0.1 \mathrm{~g} ; \mathrm{MgSO}_{4} .7 \mathrm{H}_{2} \mathrm{O}, 0.5 \mathrm{~g} ; \mathrm{KH}_{2} \mathrm{PO}_{4}, 0.1 \mathrm{~g} ; \mathrm{KCl}$, $0.05 \mathrm{~g} ; \mathrm{CaCl}_{2} .2 \mathrm{H}_{2} \mathrm{O}, 0.0008 \mathrm{~g} ; \mathrm{FeSO}_{4} .7 \mathrm{H}_{2} \mathrm{O}, 0.001 \mathrm{~g} ; \mathrm{ZnSO}_{4} .7 \mathrm{H}_{2} \mathrm{O}$, $0.0001 \mathrm{~g}$; moisture level, $55 \%$. The initial incubation temperature was $28^{\circ} \mathrm{C} \pm 1^{\circ} \mathrm{C}$. The 6-PP concentration was determined after seven days of cultivation. Moisture level was determined by dry weight, at $80^{\circ} \mathrm{C}$ for $24 \mathrm{~h}$.

\section{Headspace solid-phase microextraction (HS-SPME)}

Headspace solid-phase microextraction (HS-SPME) was used for the determination of 6-pentyl- $\alpha$-pyrone by gas chromatography (GC). Extractions were performed using a manual SPME holder with silica fused fiber coated with 100 $\mu \mathrm{m}$ polydimethylsiloxane (PDMS) (Supelco, Bellefonte, PA, USA). The fiber was conditioned according to instructions provided by the manufacturer. Sample $(0.1 \mathrm{~g})$ and $20 \mathrm{~mL}$ of a $25 \% \mathrm{NaCl}(\mathrm{w} / \mathrm{v})$ solution were placed in a $40 \mathrm{~mL}$ vial hermetically sealed with a polypropylene hole cap and PTFE/ silicone septa (Supelco, Bellefonte, PA, USA). The resuspended sample was maintained under constant magnetic stirring in water bath at $79^{\circ} \mathrm{C}$. After $2 \mathrm{~min}$, the SPME device was manually introduced into vial and the fiber was exposed to sample headspace during $29 \mathrm{~min}$ (extraction time). Thermal desorption of analytes from the fiber coating occurred in GC injector at $250^{\circ} \mathrm{C}$ for $4 \mathrm{~min}$ in splitless mode.

\section{GC Analysis of 6-PP}

Analyses were performed by gas chromatography (Varian CP3800, Palo Alto, CA, USA), equipped with a flame ionization detector. Analytes were separated on a CP Sil 5CB column (internal diameter: $0.32 \mathrm{~mm}$, length: $30 \mathrm{~m}$, film thickness: 0.25 $\mu \mathrm{m})$. Splitless mode was applied in the first 4 min for desorption and split mode with a split ratio of 35 to the end of the run time. The column was maintained at $35^{\circ} \mathrm{C}$ for $4 \mathrm{~min}$, followed by a slope-wise increment of $10^{\circ} \mathrm{C} / \mathrm{min}$ until $130^{\circ} \mathrm{C}$ which was maintained for $2 \mathrm{~min}$, and then to $240^{\circ} \mathrm{C}$ at $40^{\circ} \mathrm{C} / \mathrm{min}$. Injector and detector temperature were $250^{\circ} \mathrm{C}$. Nitrogen was used as carrier gas with a flow rate of $1.2 \mathrm{~mL} / \mathrm{min}$. Quantification was carried out by comparison of peak area with a calibration curve obtained from analyses of green coir powder $(0,1 \mathrm{~g})$ impregnated with 6-PP standard solutions. Standard solutions were prepared dissolving 6-PP (Sigma-Aldrich, St. Louis, MO, USA) in an ethanol-distilled water $(1 \mathrm{~mL}: 100 \mathrm{~mL})$ cosolvent system.

The 6-PP peak was identified among others in the injected sample by comparing the retention time of the chromatographic peak from 6-PP standard solution.

\section{Experimental Design}

A Plackett-Burman screening was used to study the effects of 15 culture variables in 16 runs with 4 replicates of the central point, in a $2^{15-11}$ factorial design. Variables studied were incubation temperature, moisture level, inoculum concentration and 12 medium components, according to Bogar et al. (2). The experimental domain is shown in Table 1. The response variable was 6-PP concentration in culture medium after seven days. A second design $\left(\mathrm{OA}_{8}\left(2^{7}\right)\right)$, as reported by Taguchi $(10)$, and using a center point with four replicates, was used to study the variables selected in Plackett-Burman screening. Table 2 shows

Table 1. Experimental domain for the Plackett-Burman screening.

\begin{tabular}{|c|c|c|c|}
\hline Factors & $\begin{array}{l}\text { Minimum } \\
\text { level (-1) }\end{array}$ & $\begin{array}{c}\text { Central } \\
(0)\end{array}$ & $\begin{array}{c}\text { Maximum } \\
\text { level }(+1)\end{array}$ \\
\hline$S:$ sucrose (g/100g support) & 0 & 1.5 & 3 \\
\hline$Y E:$ yeast extract (g/100g support) & 0 & 0.05 & 0.1 \\
\hline$N_{l}:\left(\mathrm{NH}_{4}\right)_{2} \mathrm{SO}_{4}(\mathrm{~g} / 100 \mathrm{~g}$ support $)$ & 0 & 0.047 & 0.094 \\
\hline$N 2: \mathrm{NH}_{4} \mathrm{Cl}(\mathrm{g} / 100 \mathrm{~g}$ support $)$ & 0 & 0.038 & 0.076 \\
\hline$N 3: \mathrm{NH}_{4} \mathrm{NO}_{3}$ (g/100g support) & 0 & 0.0285 & 0.057 \\
\hline$N 4: \mathrm{NaNO}_{3}(\mathrm{~g} / 100 \mathrm{~g}$ support $)$ & 0 & 0.06 & 0.12 \\
\hline$P: \mathrm{KH}_{2} \mathrm{PO}_{4}(\mathrm{~g} / 100 \mathrm{~g}$ support $)$ & 0 & 0.05 & 0.1 \\
\hline$M: \mathrm{MgSO}_{4} \times 7 \mathrm{H}_{2} \mathrm{O}(\mathrm{g} / 100 \mathrm{~g}$ support $)$ & 0 & 0.25 & 0.5 \\
\hline$K: \mathrm{KCl}$ (g/100g support) & 0 & 0.025 & 0.05 \\
\hline$C: \mathrm{CaCl}_{2} \times 2 \mathrm{H}_{2} \mathrm{O}$ (g/100g support) & 0 & 0.0004 & 0.0008 \\
\hline $\mathrm{Z}: \mathrm{ZnSO}_{4} \times 7 \mathrm{H}_{2} \mathrm{O}(\mathrm{g} / 100 \mathrm{~g}$ support $)$ & 0 & 0.00005 & 0.0001 \\
\hline$F: \mathrm{FeSO}_{4} \times 7 \mathrm{H}_{2} \mathrm{O}(\mathrm{g} / 100 \mathrm{~g}$ support $)$ & 0 & 0.0005 & 0.001 \\
\hline$W:$ moisture level $(\% \mathrm{w} / \mathrm{w})$ & 55 & 62 & 69 \\
\hline Inoculum (spores/100g support) & $2.2 \times 10^{6}$ & $2.2 \times 10^{7}$ & $2.2 \times 10^{8}$ \\
\hline Incubation temperature $\left({ }^{\circ} \mathrm{C} \pm 1^{\circ} \mathrm{C}\right)$ & 28 & 31 & 34 \\
\hline
\end{tabular}


Table 2. Experimental domain for the fractionary factorial design as recommended by Taguchi (10).

\begin{tabular}{cccc}
\hline $\begin{array}{c}\text { Factors } \\
(\mathrm{g} / 100 \mathrm{~g} \text { support })\end{array}$ & $\begin{array}{c}\text { Minimum } \\
\text { level }(-1)\end{array}$ & $\begin{array}{c}\text { Central } \\
(0)\end{array}$ & $\begin{array}{c}\text { Maximum } \\
\text { level }(+1)\end{array}$ \\
\hline$S:$ sucrose & 3.00 & 4.00 & 5.00 \\
$N_{1}:\left(\mathrm{NH}_{4}\right)_{2} \mathrm{SO}_{4}$ & 0.00 & 0.09 & 0.18 \\
$N_{4}: \mathrm{NaNO}_{3}$ & 0.00 & 0.12 & 0.24 \\
$P: \mathrm{KH}_{2} \mathrm{PO}_{4}$ & 0.10 & 0.13 & 0.16 \\
\hline
\end{tabular}

the experimental domain. Statistical analyses were performed using Statistica 6.0 (Statsoft Inc., Tulsa, OK, USA).

\section{RESULTS AND DISCUSSION}

Experimental designs were used to study nutrient supplementation needs of green coir powder and culture conditions to high production of 6-PP.

\section{Plackett-Burman screening}

Plackett-Burman screening has been applied to study several independent variables at the same time with minimal experimental runs, on the selection of important components of fermentation medium and culture conditions (2). In this work, this experimental design was used to study the effects of incubation temperature, moisture level of the solid medium, inoculum size and medium components on 6-PP production. Medium components concentration domains were set based on Sarhy-Bagnon et al. (15), that studied the production of 6-PP in solid-state fermentation using sugarcane bagasse and T. harzianum. Reasonable domains were selected as shown in Table 1. The response variable was 6-PP concentration in culture medium after seven days. Results are shown in Table 3.

The 6-PP concentration obtained after seven days varied from $0 \mathrm{mg} / \mathrm{g}$ dry matter (DM) to $3.2 \mathrm{mg} / \mathrm{gDM}$. Data were evaluated by means of analysis of variance (ANOVA), shown in Table 4. Confidence level was set at 95\%. Moisture level and concentration of ammonium nitrate, calcium chloride dihydrate and yeast extract were not significant parameters in experimental domain $(p>0.05)$ and were not considered in the model below (normalized variables):

$$
\begin{gathered}
\text { 6- } \mathrm{PP}(\mathrm{mg} / \mathrm{gDM})=0.359+0.355 \times S+0.279 \times N_{1}+0.121 \times N_{2} \\
+0.262 \times N_{4}+0.126 \times P-0.117 \times M-0.277 \times K-0.123 \times Z \\
-0.264 \times F-0.369 \times T-0.351 \times \log n
\end{gathered}
$$

\begin{tabular}{|c|c|c|c|c|c|c|c|c|c|c|c|c|c|c|c|c|}
\hline Run & \multicolumn{14}{|c|}{ Factors and levels* } & $\log n$ & $\begin{array}{c}\text { Response } \\
\text { 6-PP } \\
(\mathrm{mg} / \mathrm{gDM})\end{array}$ \\
\hline 2 & +1 & -1 & -1 & -1 & -1 & -1 & -1 & +1 & +1 & +1 & +1 & +1 & +1 & -1 & -1 & 0.06 \\
\hline 3 & -1 & +1 & -1 & -1 & -1 & +1 & +1 & -1 & -1 & +1 & +1 & +1 & -1 & +1 & -1 & 0 \\
\hline 6 & +1 & -1 & +1 & -1 & -1 & +1 & -1 & -1 & +1 & -1 & -1 & +1 & -1 & +1 & +1 & 0 \\
\hline 7 & -1 & +1 & +1 & -1 & -1 & -1 & +1 & +1 & -1 & -1 & -1 & +1 & +1 & -1 & +1 & 0.09 \\
\hline 8 & +1 & +1 & +1 & -1 & +1 & +1 & -1 & +1 & -1 & -1 & +1 & -1 & -1 & -1 & -1 & 1.87 \\
\hline 9 & -1 & -1 & -1 & +1 & +1 & +1 & -1 & +1 & -1 & -1 & -1 & +1 & +1 & +1 & -1 & 0 \\
\hline 10 & +1 & -1 & -1 & +1 & -1 & -1 & +1 & +1 & -1 & -1 & +1 & -1 & -1 & +1 & +1 & 0.02 \\
\hline 14 & +1 & -1 & +1 & +1 & -1 & +1 & +1 & -1 & -1 & +1 & -1 & -1 & +1 & -1 & -1 & 3.2 \\
\hline 15 & -1 & +1 & +1 & +1 & -1 & -1 & -1 & +1 & +1 & +1 & -1 & -1 & -1 & +1 & -1 & 0.01 \\
\hline 16 & +1 & +1 & +1 & +1 & +1 & +1 & +1 & +1 & +1 & +1 & +1 & +1 & +1 & +1 & +1 & 0.02 \\
\hline 17 & 0 & 0 & 0 & 0 & 0 & 0 & 0 & 0 & 0 & 0 & 0 & 0 & 0 & 0 & 0 & 0.4 \\
\hline 18 & 0 & 0 & 0 & 0 & 0 & 0 & 0 & 0 & 0 & 0 & 0 & 0 & 0 & 0 & 0 & 0.15 \\
\hline 19 & 0 & 0 & 0 & 0 & 0 & 0 & 0 & 0 & 0 & 0 & 0 & 0 & 0 & 0 & 0 & 0.29 \\
\hline 20 & 0 & 0 & 0 & 0 & 0 & 0 & 0 & 0 & 0 & 0 & 0 & 0 & 0 & 0 & 0 & 0.29 \\
\hline
\end{tabular}

Table 3. Experimental runs and response values of the Plackett-Burman screening. Fermentation time: 7 days.

*The experimental domain is shown in Table 1. 
Table 4. ANOVA for 6-PP produced response from the PlackettBurman screening $\left(\mathrm{r}^{2}=0.94, \mathrm{r}^{2}\right.$ ajusted for $\left.\mathrm{df}=0.93\right)$.

\begin{tabular}{lccccc}
\hline \multicolumn{1}{c}{ Factor } & $\begin{array}{c}\text { Sum of } \\
\text { Squares }\end{array}$ & df & $\begin{array}{c}\text { Mean } \\
\text { Squares }\end{array}$ & F-ratio & $\begin{array}{c}p \text { - } \\
\text { value }\end{array}$ \\
\hline$S:$ Sucrose & 2.01 & 1 & 2.01 & 192.17 & 0.001 \\
$Y E:$ Yeast Extract & 0.03 & 1 & 0.03 & 2.71 & 0.198 \\
$N_{1}:\left(\mathrm{NH}_{4}\right)_{2} \mathrm{SO}_{4}$ & 1.25 & 1 & 1.25 & 119.00 & 0.002 \\
$N_{2}: \mathrm{NH}_{4} \mathrm{Cl}$ & 0.23 & 1 & 0.23 & 22.31 & 0.018 \\
$N_{3}: \mathrm{NH}_{4} \mathrm{NO}_{3}$ & 0.03 & 1 & 0.03 & 3.10 & 0.176 \\
$N_{4}: \mathrm{NaNO}_{3}$ & 1.09 & 1 & 1.09 & 104.40 & 0.002 \\
$P: \mathrm{KH}_{2} \mathrm{PO}_{4}$ & 0.25 & 1 & 0.25 & 24.28 & 0.016 \\
$M: \mathrm{MgSO}_{4}$ & 0.22 & 1 & 0.22 & 20.95 & 0.02 \\
$K: \mathrm{KCl}_{C:}$ & 1.23 & 1 & 1.23 & 117.49 & 0.002 \\
$\mathrm{CaCl}$ & 0.03 & 1 & 0.03 & 2.97 & 0.183 \\
$Z: \mathrm{ZnSO}_{4}$ & 0.24 & 1 & 0.24 & 23.20 & 0.017 \\
$F: \mathrm{FeSO}$ & 1.12 & 1 & 1.12 & 106.43 & 0.002 \\
$W: \mathrm{Moisture} \mathrm{level}_{4}$ & 0.03 & 1 & 0.03 & 3.17 & 0.173 \\
$T: \mathrm{Temperature}$ & 2.17 & 1 & 2.17 & 207.36 & 0.001 \\
Log $n^{*}$ & 1.97 & 1 & 1.97 & 188.01 & 0.001 \\
Lack of Fit & 0.03 & 1 & 0.03 & 2.64 & 0.203 \\
Pure Error & 0.03 & 3 & 0.01 & & \\
Total (corr.) & 11.98 & 19 & & & \\
\hline
\end{tabular}

$*_{n}$ : inoculum (spores/100 g support).

where $S$ : sucrose; $N_{1}:\left(\mathrm{NH}_{4}\right)_{2} \mathrm{SO}_{4} ; N_{2}: \mathrm{NH}_{4} \mathrm{Cl} ; N_{4}: \mathrm{NaNO}_{3} ; P$ :

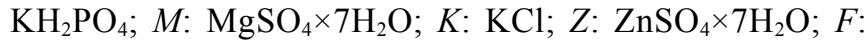
$\mathrm{FeSO}_{4} \times 7 \mathrm{H}_{2} \mathrm{O} ; T$ : incubation temperature; $n$ : inoculum concentration.

The coefficient of determination $\left(r^{2}\right)$ was 0.94 , what means that the model explains $94 \%$ of variability in response. Adjusted $\mathrm{r}^{2}$ statistic was also high (0.93). Analysis showed that curvature was not important to the model and that the linear model obtained to describe 6-PP production seems to be suitable for observed data.

The model predicted a negative effect of magnesium sulfate heptahydrate, potassium chloride, zinc sulfate heptahydrate and ferrous sulfate heptahydrate over 6-PP production. It means that the greatest yield of 6-PP would be obtained when each of these variables were set at the lowest values within the domain range. In this case, the lowest value was zero. These compounds must be absent of culture medium for better 6-PP production. Quite the contrary, the model indicated that the best 6-PP production would be obtained when sucrose, potassium dihydrogen phosphate, ammonium sulfate, sodium nitrate and ammonium chloride concentrations were used at maximum levels.

In this study, Placket-Burman design was also used to compare nitrogen sources by normalized coefficients of variables in the model. Since the nitrogen content was equivalent in different nitrogen compounds, the nature of nitrogen source seems to be important to 6-PP production. The model indicated that ammonium nitrate would have no significative effect over the production and the variation in ammonium sulfate and sodium nitrate would be of greater influence on 6-PP yield than ammonium chloride.

The temperature domain studied varied from $28^{\circ} \mathrm{C}$ to $34^{\circ} \mathrm{C}$. The upper level of the temperature domain, sub-optimal condition for fungi growth, was chosen based on the observed by Rocha-Valadez et al. (13) that disadvantageous growth conditions lead to higher 6-PP production. In the present work, the model indicated that the lowest temperature studied would lead to higher yields and this variable was set at $28^{\circ} \mathrm{C}$ for the next experiments. The production at lower temperatures should be studied, but temperatures lower than $28^{\circ} \mathrm{C}$ were difficult to maintain at laboratory conditions.

It was observed a negative effect of inoculum concentration on the production. Then, inoculum concentration was fixed at the lowest value studied $\left(2.2 \times 10^{6}\right.$ spores $/ 100 \mathrm{~g}$ support $)$. However, it is recommended to consider lower values of this variable in scale up studies.

Experiments, performed in triplicate, were conducted to verify the yield predicted by statistical model. Sucrose, potassium dihydrogen phosphate, ammonium sulfate, sodium nitrate and ammonium chloride concentrations were adjusted to the highest value within the usable range, temperature was maintained at $28^{\circ} \mathrm{C}$, moisture level was $55 \%$ and inoculum concentration was set at $2.2 \times 10^{6}$ spores $/ 100 \mathrm{~g}$ support. Parameters suggested by the model resulted in $2.5 \pm 0.29 \mathrm{mg} / \mathrm{gDM}$ of 6-PP concentration after seven days. This value is a little lower than that obtained in run 14 of the Plackett-Burman design (Table 3). It is possible because some variables were not significant and the best conditions indicated by the model were not identical to some run. Moreover, the aim of this screening design used here to reduce complexity of the medium culture was achieved. Furthermore, the 6-PP concentration obtained after this step of optimization was about 2.5 times higher than the initial one $(0.8 \pm 0.22 \mathrm{mg} / \mathrm{gDM})$.

\section{Fractionary factorial design}

Data obtained from the Plackett-Burman screening were applied to design a second set of experiments. A fractionary factorial design $\left(\mathrm{OA}_{8}\left(2^{7}\right)\right)$, as recommended by Taguchi (10), were used to study four variables: sucrose, sodium nitrate, ammonium sulfate and potassium dihydrogen phosphate concentrations and the interactions between sucrose and sodium nitrate, sucrose and ammonium sulfate, sodium nitrate and ammonium sulfate. This design was similar to that one described by Fiaux de Medeiros et al. (6). Moisture level used in this design corresponded to the inferior value studied before (55\%), temperature was set at $28^{\circ} \mathrm{C} \pm 1^{\circ} \mathrm{C}$ and inoculum concentration at $2.2 \times 10^{6}$ spores $/ 100 \mathrm{~g}$ support. Four central point replicates were accomplished. The selected experimental domains are shown in Table 2. The 6-PP concentration in culture medium after seven days was again the response variable. Experimental runs and results are shown in Table 5. 
The 6-PP concentration obtained after seven days varied from $0.04 \mathrm{mg} / \mathrm{gDM}$ to $4.89 \mathrm{mg} / \mathrm{gDM}$. Analysis of variance (ANOVA) showed that variation of sucrose and potassium dihydrogen phosphate concentrations and all interactions between nutrients studied had no significative effect on 6-PP production within the experimental domain (Table 6). The confidence level was set at $95 \%$.

The following mathematical equation was generated by statistical analysis as a model to describe experimental results (normalized variables):

$$
\text { 6- } \mathrm{PP}(\mathrm{mg} / \mathrm{gDM})=2.756+0.939 \times N_{1}+1.449 \times N_{4}
$$

where $N_{l}$ and $N_{4}$ refer to concentration of $\left(\mathrm{NH}_{4}\right)_{2} \mathrm{SO}_{4}$ and $\mathrm{NaNO}_{3}$, respectively.

Statistical analysis indicated a good fit of the model $\left(\mathrm{r}^{2}=\right.$ 0.94 and $r^{2}$ adjusted $=0.93$ ). The model suggested that the greatest 6-PP production within the experimental domain would be obtained when both nitrogen sources were at the highest concentration whereas variation of sucrose and potassium dihydrogen phosphate concentration would be not significative. The lowest concentration within the second design experimental domain was chosen for these last two compounds.

Two sequential experimental designs analysis suggested following culture conditions (100 g support $)^{-1}$ : sucrose concentration, $3 \mathrm{~g}$; sodium nitrate concentration, $0.24 \mathrm{~g}$; ammonium sulfate concentration, $0.18 \mathrm{~g}$; potassium dihydrogen phosphate concentration, $0.1 \mathrm{~g}$; inoculum concentration, $2.2 \times 10^{6}$ spores; moisture level, $55 \%$. The incubation temperature was $28^{\circ} \mathrm{C}$.

Table 5. Experimental runs and response values of the second experimental design. Inoculum concentration: $2.2 \times 10^{6}$ spores / $100 \mathrm{~g}$ support; moisture level, $55 \%$; incubation temperature: $28^{\circ} \mathrm{C}$; fermentation time: 7 days.

\begin{tabular}{cccccc}
\hline \multirow{2}{*}{ Run } & \multicolumn{3}{c}{ Factors and levels* } & \multicolumn{2}{c}{ Response } \\
\cline { 2 - 6 } & $S$ & $N_{4}$ & $N_{1}$ & $P$ & 6-PP $(\mathrm{mg} / \mathrm{gDM})$ \\
\hline 1 & -1 & -1 & -1 & -1 & 0.08 \\
2 & -1 & -1 & +1 & +1 & 2.2 \\
3 & -1 & +1 & -1 & +1 & 3.38 \\
4 & -1 & +1 & +1 & -1 & 4.89 \\
5 & +1 & -1 & -1 & +1 & 0.04 \\
6 & +1 & -1 & +1 & -1 & 2.37 \\
7 & +1 & +1 & -1 & -1 & 3.23 \\
8 & +1 & +1 & +1 & +1 & 4.78 \\
9 & 0 & 0 & 0 & 0 & 2.84 \\
10 & 0 & 0 & 0 & 0 & 3.3 \\
11 & 0 & 0 & 0 & 0 & 2.4 \\
12 & 0 & 0 & 0 & 0 & 3.56 \\
\hline
\end{tabular}

*The experimental domain is shown in Table 2.
The model predicted a production of $5.14 \mathrm{mg}$ of $6-\mathrm{PP} /$ gDM when variables were set at the values above. Experiments performed in triplicate were conducted to confirm the 6-PP production predicted by the model. Analysis of produced 6-PP were carried out after seven, nine and twelve days of culture (Fig. 1). The 6-PP production after seven days was $5.0 \pm 0.79 \mathrm{mg} / \mathrm{gDM}$. This result matched the prediction and it was about six times higher than the initial one $(0.8 \pm$ $0.22 \mathrm{mg} / \mathrm{gDM}$ ). This production is more than $50 \%$ higher than the maximum reported in literature in solid-state fermentation $(3.0 \mathrm{mg} / \mathrm{gDM})(1,15)$.

Table 6. ANOVA for 6-PP produced response from the second experimental design $\left(\mathrm{r}^{2}=0.94, \mathrm{r}^{2}\right.$ adjusted for $\left.\mathrm{df}=0.93\right)$.

\begin{tabular}{lccccc}
\hline Factor & $\begin{array}{c}\text { Sum of } \\
\text { Squares }\end{array}$ & df & $\begin{array}{c}\text { Mean } \\
\text { Squares }\end{array}$ & F-ratio & $\begin{array}{c}p- \\
\text { value }\end{array}$ \\
\hline$S:$ Sucrose & 0.00 & 1 & 0 & 0.01 & 0.931 \\
$N_{4}: \mathrm{NaNO}_{3}$ & 16.78 & 1 & 16.78 & 64.95 & 0.004 \\
$N_{1}:\left(\mathrm{NH}_{4}\right)_{2} \mathrm{SO}_{4}$ & 7.04 & 1 & 7.04 & 27.24 & 0.014 \\
$P: \mathrm{KH}_{2} \mathrm{PO}_{4}$ & 0.00 & 1 & 0.00 & 0.01 & 0.917 \\
$S^{\prime} N_{4}$ & 0.02 & 1 & 0.02 & 0.07 & 0.803 \\
$S^{\prime} N_{1}$ & 0.01 & 1 & 0.01 & 0.03 & 0.876 \\
$N_{4} N_{1}$ & 0.25 & 1 & 0.25 & 0.96 & 0.399 \\
Lack of Fit & 0.44 & 1 & 0.44 & 1.69 & 0.285 \\
Pure Error & 0.77 & 3 & 0.26 & & \\
Total (corr.) & 25.31 & 11 & & & \\
\hline
\end{tabular}

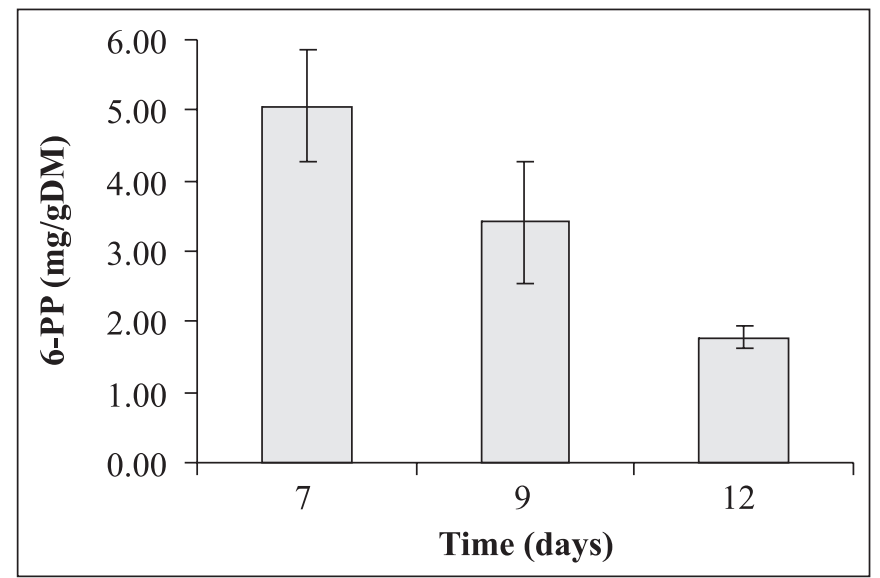

Figure 1. Evolution of 6-PP concentration at culture conditions suggested after analysis of the two sequential experimental designs. Data reported are the average of three replicates. Culture conditions (100 g support) ${ }^{-1}$ : sucrose, $3 \mathrm{~g}$; sodium nitrate, 0.24 $\mathrm{g}$; ammonium sulfate, $0.18 \mathrm{~g}$; potassium dihydrogen phosphate, $0.1 \mathrm{~g}$; inoculum concentration, $2.2 \times 10^{6}$ spores; moisture level, $55 \%$. Incubation temperature: $28^{\circ} \mathrm{C}$. 
It was observed that 6-PP concentration gradually decreased after seven days of culture, reaching $1.8 \pm 0.15 \mathrm{mg} / \mathrm{gDM}$ on twelfth day. This decrease was reported in liquid medium fermentation $(7,8,13,17)$ but it was not observed in the solid-state fermentations realized by Sarhy-Bagnon et al. (15). It is possible that the high 6PP concentration obtained in this work had activated fungi metabolism to reduce this concentration as a defense mechanism trying to avoid toxic effects (7). Humidity was also determined and it was $54.4 \% \pm 1.37 \%$ at the end of kinetics.

In conclusion, the 6-PP production by T. harzianum 4040 in solid-state fermentation was successfully enhanced by using statistical experimental design. A Placket-Burman screening followed by a fractionary factorial design as reported by Taguchi were used to reduce medium complexity and to select culture conditions. This approach led to a production of $5.0 \pm 0.79 \mathrm{mg}$ 6-PP /gDM after seven days of growth. This value is six times higher than that obtained at initial conditions $(0.8 \mathrm{mg} / \mathrm{gDM})$. Green coir powder is a promising support for production of 6PP by solid-state fermentation.

\section{ACKNOWLEDGEMENTS}

This study was supported by CNPq - Brazil (Conselho Nacional de Desenvolvimento Científico e Tecnológico), FUJB (Fundação Universitária José Bonifácio) and FAPERJ (Fundação Carlos Chagas Filho de Amparo à Pesquisa do Estado do Rio de Janeiro).

\section{RESUMO}

\section{Produção de 6-pentil- $\alpha$-pirona por Trichoderma harzianum em fermentação em estado sólido}

Muitas espécies do gênero Trichoderma são capazes de produzir a substância 6-pentil- $\alpha$-pirona (6-PP), uma lactona com aroma característico de coco. No presente trabalho, vários parâmetros de cultura foram estudados para aumentar a produção de 6-PP por Trichoderma harzianum 4040 em fermentação em estado sólido. Pó da casca de coco verde adicionado à uma solução nutriente foi usado como material de suporte para a fermentação. Um planejamento experimental de varredura segundo a técnica de Plackett-Burman foi aplicado, seguido de um planejamento fatorial fracionário. No domínio experimental estudado, as melhores condições de cultura foram (100 $\mathrm{g}$ suporte $)^{-1}$ : sacarose, $3 \mathrm{~g}$; $\mathrm{NaNO}_{3}, 0,24 \mathrm{~g} ;\left(\mathrm{NH}_{4}\right)_{2} \mathrm{SO}_{4}, 0,18 \mathrm{~g} ; \mathrm{KH}_{2} \mathrm{PO}{ }_{4}, 0,1 \mathrm{~g}$; produção do inóculo, $2,2 \times 10^{6}$ esporos; umidade, $55 \%$. A temperatura estabelecida foi de $28^{\circ} \mathrm{C}$. Esse estudo conduziu à concentração de 6-PP seis vezes maior $(5,0 \mathrm{mg} / \mathrm{g}$ de matéria seca) do que a inicial $(0,8 \mathrm{mg} / \mathrm{g}$ de matéria seca) após sete dias de cultivo.

Palavras-chave: 6 -pentil- $\alpha$-pirona, Trichoderma harzianum, fermentação em estado sólido, planejamento experimental

\section{REFERENCES}

1. Araujo, A.A.; Pastore, G.M.; Berger, R.G. (2002). Production of coconut aroma by fungi cultivation in solid-state fermentation. Appl. Biochem. Biotechnol., 98-100, 747-751.

2. Bogar, B.; Szakacs, G.; Linden, J.C.; Pandey, A.; Tengerdy, R.P. (2003). Optimization of phytase production by solid substrate fermentation. J. Ind. Microbiol. Biotechnol., 30 (3), 183-189.

3. Bonnarme, P.; Djian, A.; Latrasse, A.; Féron, G.; Giniès, C.; Durand, A.; Le Queré, J.L. (1997). Production of 6-pentyl- $\alpha$-pyrone by Trichoderma sp. from vegetable oils. J. Biotechnol., 56 (2), 143150 .

4. Carrijo, A.O.; Liz, R.S.; Makishima, N. (2002). Fibra da casca do coco verde como substrato agrícola. Hortic. Bras., 20 (4), 533-535.

5. Collins, R.P.; Halim, A.F. (1972). Characterization of the major aroma constituent of the fungus Trichoderma viride (Pers.). J. Agric. Food Chem., 20 (2), 437-438.

6. Fiaux de Medeiros, S.; Avery, M.A.; Avery, B.; Leite, S.G.F.; Freitas, A.C.C.; Williamson, J.S. (2002). Biotransformation of 10 deoxoartemisinin to its $7 \beta$-hydroxy derivative by Mucor ramannianus. Biotechnol. Lett., 24 (11), 937-941.

7. Galindo, E.; Flores, C.; Larralde-Corona, P.; Corkidi-Blanco, G.; Rocha-Valadez, J.A.; Serrano-Carreón, L. (2004). Production of 6pentyl- $\alpha$-pyrone by Trichoderma harzianum cultured in unbaffled and baffled shake flasks. Biochem. Eng. J., 18 (1), 1-8.

8. Kalyani, A.; Prapulla, S.G.; Karanth, N.G. (2000). Study on the production of 6-pentyl- $\alpha$-pyrone using two methods of fermentation. Appl. Microbiol. Biotechnol., 53 (5), 610-612.

9. Linde, G.A.; Magagnin, G.; Costa, J.A.V.; Bertolin, T.E.; Colauto, N.B. (2007). Column bioreactor use for optimization of pectinase production in solid substrate cultivation. Braz. J. Microbiol., 38 (3), 557-562.

10. Logothetis, N.; Wynn, H.P. (1989). Quality through design Experimental design, off-line quality control and Taguchi's contributions. Clarendon Press, Oxford.

11. Longo, M.A.; Sanromán, M.A. (2006). Production of food aroma compounds. Food Technol. Biotecnol., 44 (3), 335-353.

12. Parekh, S.; Vinci, V.A.; Strobel, R.J. (2000). Improvement of microbial strains and fermentation processes. Appl. Microbiol. Biotechnol. 54 (3), 287-301.

13. Rocha-Valadez, J.A.; Estrada, M.; Galindo, E.; Serrano-Carreón, L. (2006). From shake flasks to stirred fermentors: Scale-up of an extractive fermentation process for 6-pentyl- $\alpha$-pyrone production by Trichoderma harzianum using volumetric power input. Process Biochem., 41 (6), 1347-1352.

14. Rosa, M.F.; Santos, F.J.S.; Montenegro, A.A.T.; Abreu, F.A.P.; Correia, D.; Araújo, F.B.S.; Norões, E.R.V. (2001). Caracterização do pó da casca de coco verde usado como substrato agrícola - Comunicado Técnico 54. Embrapa Agroindústria Tropical, Fortaleza.

15. Sarhy-Bagnon, V.; Lozano, P; Saucedo Castañeda, G; Roussos, S. (2000). Production of 6-pentyl- $\alpha$-pyrone by Trichoderma harzianum in liquid and solid state cultures. Process Biochem., 36 (1-2), 103 109.

16. Serrano-Carreón, L.; Flores, C.; Rodríguez, B.; Galindo, E. (2004). Rhizoctonia solani, an elicitor of 6-pentyl- $\alpha$-pyrone production by Trichoderma harzianum in a two liquid phases, extractive fermentation system. Biotechnol. Lett., 26 (18), 1403-1406.

17. Serrano-Carreón, L.; Hathout, Y.; Bensoussan, M.; Belin, J-M. (1992). Production of 6-pentyl- $\alpha$-pyrone by Trichoderma harzianum from 18:n fatty acid methyl esters. Biotechnol. Lett., 14 (11), 1019. 1024.

18. Weuster-Botz, D. (2000). Experimental design for fermentation media development: statistical design or global random search? $J$. Biosci. Bioeng., 90 (5), 473-483. 